University of Nebraska - Lincoln

DigitalCommons@University of Nebraska - Lincoln

$5-2009$

\title{
A European "Equivalent" to United States Export Controls: European Law on the Control of International Trade in Dual-Use Space Technologies
}

Frans von der Dunk

University of Nebraska - Lincoln, fvonderdunk2@unl.edu

Follow this and additional works at: https://digitalcommons.unl.edu/spacelaw

Part of the Air and Space Law Commons

von der Dunk, Frans, "A European "Equivalent" to United States Export Controls: European Law on the Control of International Trade in Dual-Use Space Technologies" (2009). Space, Cyber, and Telecommunications Law Program Faculty Publications. 10.

https://digitalcommons.unl.edu/spacelaw/10

This Article is brought to you for free and open access by the Law, College of at DigitalCommons@University of Nebraska - Lincoln. It has been accepted for inclusion in Space, Cyber, and Telecommunications Law Program Faculty Publications by an authorized administrator of DigitalCommons@University of Nebraska - Lincoln. 


\title{
A European "Equivalent" to United States Export Controls: European Law on the Control of International Trade in Dual-Use Space Technologies
}

\author{
Frans G. von der Dunk \\ University of Nebraska College of Law
}

\begin{abstract}
This article analyzes the system developed within Europe, more precisely within the European Union through European Community law, to address the securitysensitive issues involved in the export of hardware, software, and knowledge for the purpose of space activities and major space applications. The subject is introduced with reference to the far better known export control developments within the United States, such as those concerning International Traffic in Arms Regulations, and the international understandings under the Missile Technology Control Regime and Wassenaar Arrangement. European Community Regulations for export controls provide for a complex system of balances between national sovereignty and Europe-wide harmonization. This European Community regime, though ultimately still dependent upon individual state's sovereign controls, establishes an interesting measure of international harmonization in security-sensitive export controls. Although the European Community regime is fraught with many complexities, it manages to avoid some of the pitfalls evident in the United States and international regimes, notably the confusing discussions on discerning weaponry proper from other space items with dual-use potential. This is the result mainly of an approach characterized by a primary intention to harmonize, rather than to apply strict controls per se, resulting in a transparency and consistency that are not only valuable to commercial entrepreneurs, but also to those concerned primarily with the security risks posed by the international space industry. As for the space industry in particular, it is helpful that the European Community regime specifically carves out civil space activities, for example if conducted within the context of the European Space Agency or national space agency activities.
\end{abstract}




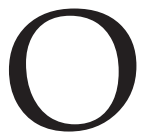

ne of the most hotly debated issues in current commercial and civil space activities concerns the United States (U.S.) International Traffic in Arms Regulations (ITAR). This most specific and substantive element of U.S. export controls on sensitive technologies has considerable effects on the possibilities for the U.S. space industry to compete in relevant international markets, and on the possibilities of non-U.S. space operators, public and private, to choose U.S. technologies and attendant hardware, software, and know-how for their operations, should they wish to do so. ${ }^{1}$ And indeed, though the many areas where U.S. technologies are key to undertaking a certain space activity may very gradually be declining, they are still numerous enough to make such attention understandable.

At the same time, one should not forget that other states, including longstanding geopolitical allies of the U.S., have similar worries. These states would not like to see sensitive dual-use technology falling into the "wrong hands," whether of states principally antagonistic to Western politics, culture, and society or of non-state actors with similar views of the West. From that perspective, the U.S. export control regime, which is most noticeably embodied in ITAR, is no more than one national example of a broader effort to try to protect such security interests.

The current contribution tries to add to that perspective by highlighting how, in particular, the European states members of the European Union (EU) have undertaken collective efforts in the same direction, as part of their policy approach to implement the international arrangements on this level. Where appropriate, some high-level references and comparisons with the U.S. regime are made to further underscore such an analysis.

\section{The United States Export Controls Regime}

The U.S. export controls regime started to make serious inroads into the commercial space sector as soon as the latter started to grow fundamentally beyond subcontractor status vis-à-vis the government and the National Aeronautics and Space Administration (NASA), which occurred in the 1980s. ${ }^{2}$ In hindsight, it was inevitable that the high-key technology character of almost all space activities, and their inherent dual-use character, would raise issues related to the national security of the U.S. at the highest level. After all, at the same time that space became increasingly subject to commercial interests, the geopolitical scene was changing from an essentially bipolar world to a mul- 
tipolar one. In addition to a number of additional states that are important from a security perspective, certain non-state actors evolved into an international security concern as well. ${ }^{3}$ The immediate concerns, from a space perspective, have been focused on the launching sector. Ever since Sputnik, it has been clear that the technical differentiation between a missile capable of delivering weapons - including those of mass destruction - to terrestrial targets, and a launch vehicle capable of delivering a payload in orbit, has been negligible.

The U.S. included such systems, and all components and key technologies involved, in the U.S. Munitions List (USML), ${ }^{4}$ which under the Arms Export Control Act (AECA), ${ }^{5}$ was subject to the jurisdiction of the U.S. Department of State. ITAR was drafted to control the export of such systems, components, and technologies to anywhere outside the U.S. where their presence might result in security threats. ${ }^{6}$ From a teleological perspective, launch systems capable of delivering bombs were essentially comparable to munitions, especially since the key phrase for invoking the above regime under the AECA was now phrased as widely as "defense articles."

Chapter IV of the USML comprised inter alia:

(a) Rockets (including but not limited to meteorological and other sounding rockets) ... as well as launchers for such defense articles ... (b) Launch vehicles and missile and anti-missile systems including but not limited to guided, tactical and strategic missiles, launchers, and systems ... (h) All specifically designed or modified components, parts, accessories, attachments, and associated equipment for the articles in this category ... (i) Technical data ... and defense services ... directly related to the defense articles enumerated in paragraphs (a) through (h) of this category. ${ }^{8}$

Inclusion in such a list was perhaps less obvious with regard to satellites, even as there could be little doubt that satellites were already supporting military capabilities in many ways. Examples involved the provision of intelligence, the provision of secure communications, and the guidance of missile and other weapon systems. Once satellite communications emerged as a viable sector in the 1980s, the inclusion of satellites, their components and technologies in the USML became increasingly subject to debate. ${ }^{9}$

In terms of space activities, moreover, the U.S. Commerce Control List $(\mathrm{CCL}){ }^{10}$ existing in parallel to the USML played an important role, as well. The net result of the debate referred to above was a gradual transfer of all relevant dual-use items (e.g., satellites, components, and technologies) from the USML to the CCL, and hence from the jurisdiction of the U.S. Department of State to the U.S. Department of Commerce. ${ }^{11}$ The CCL was ruled by the Export Administration Act (EAA), ${ }^{12}$ which dealt with the export of dual-use items for which an export authorization was required under the Export Administration Regulations (EAR). 
"Dual-use" items were, of course, a well-known phenomenon across the space arena, and would without a doubt include satellites and their components and technology for almost all imaginable purposes. Real-time remote sensing of medium or high resolution would not only be helpful for intelligence gathering, but offered numerous civil and potentially commercial benefits, such as in environmental, urban planning, and disaster management contexts. Satellite navigation, certainly if of a certain level of precision, could guide cars, ships, and aircraft to their destinations as much as bombs and cruise missiles. And of course, telecommunications using space was already a major commercial sector for some time; not only does today's battleground efficiency crucially depend upon large-volume satellite communication capabilities, but so do multiple commercial and other civil applications. As long as such space items were under the control of the Department of Commerce, however, there was a presumption that unless direct threats to U.S. security could be discerned, export should be allowed to boost the competitiveness of the U.S. commercial space industry in the international arena. ${ }^{13}$

This changed fundamentally in the course of the 1990s, following the Tiananmen Square massacre in 1989, the Republican return to a U.S. Congressional majority in 1994, and two Long March failures with U.S. satellites in 1995 and $1996 .^{14}$ The net result was the undoing of the transfer of dual-use technologies from the Department of State and the USML to the Department of Commerce and the CCL over the 1988-1996 periods. Most notably, the 1998 Strom Thurmond National Defense Authorization Act ${ }^{15}$ placed all satellites, satellite components, and satellite technologies back on the USML. ${ }^{16}$ Once an item is seen as falling within the USML, and hence, ruled by ITAR as determined by the relevant agencies within the U.S. Department of State, it can no longer claim the relative benefits of the export control regime falling under the jurisdiction of the Department of Commerce, which strikes a different balance between the security interests of the government and the commercial interests of prospective exporters.

Because of the above, Chapter XV of the USML, dealing with "Spacecraft Systems and Associated Equipment," now encompasses:

(a) Spacecraft, including communications satellites, remote sensing satellites, scientific satellites, research satellites, navigation satellites, experimental, and multi-mission satellites ... (b) Ground control stations for telemetry, tracking and control of spacecraft or satellites, or employing any of the cryptographic items controlled ... (c) Global Positioning System (GPS) receiving equipment specifically designed, modified, or configured for military use ... (e) All specifically designed or modified systems or subsystems, components, parts, accessories, attachments, and associated equipment for the articles in this category ... (f) Technical data ... and defense services ... directly related to the articles enumerated in paragraphs (a) through (e) 
of this category, as well as detailed design, development, manufacturing or production data for all spacecraft and specifically designed or modified components for all spacecraft systems. ${ }^{17}$

A final point of note for the present analysis concerns the exemption of North Atlantic Treaty Organization (NATO) member states and major nonNATO allies from ITAR, which was originally created in a more or less comprehensive fashion under the 1998 Strom Thurmond Act. However, this exemption could still be revoked (and this has indeed occurred) if appropriate in furtherance of the security and foreign policy of the U.S. ${ }^{18}$ A similar fate befell the special relationship between the U.S. and Canada. ${ }^{19}$

In view of the fact that the U.S. was both the world's primary military power and its preeminent space power, it was obvious that it would play a leading role in drafting comparable instruments on the international level. Indeed, much of the approach taken at the national level and the substance addressed in the legal instruments summarily discussed here has transpired to the international level, and as such has also influenced the European regime to be discussed shortly in major ways. Concomitantly, it will be clear that these international arrangements do not simply copy the U.S. national arrangements. This is the case for an array of reasons.

\section{The Missile Technology and Control Regime and the Wassenaar Arrangement}

The first of such international arrangements relevant today is the Missile Technology Control Regime (MTCR). ${ }^{20}$ The MTCR was initiated in an effort to control the proliferation of weapons of mass destruction, i.e., nuclear, chemical, and biological weapons, ${ }^{21}$ and their means of delivery. In other words, it focuses on rockets, and hence, almost automatically has an impact on launch vehicles for peaceful, civil, and commercial missions, and their payloads. The MTCR is an informal and voluntary association of, as of today, 34 participating states ${ }^{22}$ sharing the goal of non-proliferation and willing to coordinate national export licensing efforts to that end. The MTCR was established in 1987, by Canada, France, Germany, Italy, Japan, the United Kingdom, and the U.S. These states had considered it necessary to counter unwanted proliferation by establishing some measure of control over, and transparency with regard to, the transfer outside of their respective territories and jurisdictions of missile equipment, material, and related technologies usable for systems capable of delivering weapons of mass destruction.

The MTCR Guidelines for Sensitive Missile-Relevant Transfers ${ }^{23}$ form the cornerstone of the MTCR, offering a set of common export policy guidelines applied to an integral common list of controlled items - the MTCR Equip- 
ment, Software, and Technology Annex. ${ }^{24}$ Decisions on the guidelines and the contents of the lists are taken by consensus in order to enhance adherence, as such still voluntary, and partner states regularly exchange information about relevant national export licensing issues. As a result, many states, not just the MTCR partners, have introduced export-licensing measures on such items as rocket and other delivery systems, and related equipment, material, and technology.

The second major international arrangement of relevance here concerned the 1995 Wassenaar Arrangement. ${ }^{25}$ It currently counts 40 participating states: ${ }^{26}$ largely, the same as those participating in the MTCR. ${ }^{27}$ Just like the MTCR, the Wassenaar Arrangement is a global, formally non-binding arrangement on export controls - but broader, in this case, as it applies to conventional weapons more generally, and in addition to any sensitive dual-use goods and technologies.

Historically, the Wassenaar Arrangement evolved from the Coordinating Committee on Multilateral Export Controls (CoCom) regime of the Cold War era. ${ }^{28}$ The main difference from that perspective concerns Russia, in its prior manifestation as Soviet Union the original key target of the regime. By contrast, it is now party to the Arrangement, just as it has become a partner under the MTCR, in an effort to preclude proliferation of its relevant capabilities to third states in the changing geopolitical environment.

The Wassenaar Arrangement was designed to promote transparency and greater responsibility in transfers of conventional arms, dual-use goods, and dual-use technologies. Participating states commit themselves to ensure through national policies and, where appropriate, regulations that cross-border transfers of these items do not contribute to the development or enhancement of military capabilities of certain states considered a potential threat to international security and stability. ${ }^{29}$

Like with the MTCR, under the Wassenaar Arrangement, the decision to allow or deny transfer of any item remains the sole responsibility of each individual participating state. ${ }^{30}$ Thus, in fact export controls differ from state to state-for example, in terms of documentation required, license fees, length of time to get a license, and duration of validity of the license. Furthermore, and most fundamentally there are differences in principle as to which export would be authorized. Thus, the participating states only agree to notify transfers and denials of, as well as to control export of, all items in the List of Dual-Use Goods and Technologies and the List of Munitions, annexed to the Arrangement. ${ }^{31}$ In any event, "controls do not apply to 'technology' [including software] 'in the public domain,' to 'basic scientific research,' or to the minimum necessary information for patent applications." 32 The List has two annexes of sensitive items and of very sensitive items, respectively, to which different levels of control should be applied, and are reviewed regularly to 
reflect technological developments. Finally, the participating states agree to exchange general information on risks associated with transfers of conventional arms and dual-use goods and technologies in order to consider, where necessary, the scope for coordinating national control policies to combat these risks. ${ }^{33}$

The relationship between MTCR and Wassenaar Arrangement in general terms reflects the relationship in the U.S. context between the AECA/Department of State/USML/ITAR and EAA/Department of Commerce/CCL/EAR regimes. In roughly equivalent fashion, like the AECA/Department of State/ USML/ITAR regime, the MTCR developed primarily with a focus on arms and munitions (in space terms, missiles/launch vehicles), whereas, like the EAA/Department of Commerce/CCL/EAR regime, the Wassenaar Arrangement tried to capture the more comprehensive spectrum of dual-use goods, services, and technologies (in space terms, including notably, satellites).

Consequently, similar complications arose as to where a particular item would best be dealt with; also, the Wassenaar Arrangement had a List of Munitions to control. However, in the case of the U.S. a more or less permanent tug-of-war between the two regimes had been the result, leading to the shifting back and forth, especially of satellites, including components and technologies. By contrast, the voluntary character of the two international regimes and the remaining sovereign discretion of the individual states parties thereto to establish and maintain their own export control regimes as appropriate, caused such conflicts in this context to be absent, at least from public view. ${ }^{34}$

Neither the MTCR nor the Wassenaar Arrangement recognizes the EU in any substantive manner; neither are they, as indicated, in themselves formally binding treaties. The last consideration also played a major role in the determination within the U.S. to maintain a more legally enforceable and substantively tighter domestic regime by means of ITAR and other control mechanisms. For Europe, both of the above concerns mattered.

As a result, within Europe the desire arose to deal further with the same issue in a more classical, legally binding format, which led to the enunciation of a truly European regime for the control of exports of dual-use items and technology properly. In the process, the complications resulting from dealing with security-sensitive exports by means of two different regimes could to some extent be avoided. The European governments would take care to align developments in the context of that legal regime on a continuous basis with updates in both the MTCR and with the Wassenaar Arrangement, which after all amongst its participating states counts the main non-European allies, the U.S. and Canada. In addition, more or less like in the U.S., this regime has an obvious bearing upon the specific areas of space industry and commerce, because of the high proportion of military, defense, security, and dual-use issues involved in the human space endeavor. 


\section{Europe and Military, Defense, Security, and Dual-Use Issues}

It was not altogether self-evident for a more or less European-wide regime to deal with such military, defense, security, and dual-use issues to be realized, whether the focus would be on space only, or more comprehensively, on all security and dual-use issues. Neither of the two principal instruments for European integration relevant here, the European Community (EC)/EU and the European Space Agency (ESA), were namely intended to play any role in such sovereignty-sensitive areas.

ESA was established in 1975, to pool the financial and technical resources of its member states ${ }^{35}$ for the purposes of outer space, in terms primarily of research and development. ${ }^{36}$ ESA, in accordance with its constitutive Convention, is supposed to "provide for and to promote, for exclusively peaceful purposes, cooperation among European States in space research and technology and their space applications, with a view to their being used for scientific purposes and for operational space applications systems."37

Traditionally this has been interpreted as a ban on ESA involvement in any space activities of a military or defense nature; ESA member states at least for this purpose interpreting "exclusively peaceful purposes" in a strict fashion. ${ }^{38}$ Relevant clauses in contracts or agreements with ESA as a partner should therefore continue to include references to peaceful uses, whatever their precise meaning might currently be. When the launcher development and further marketing activities were branched off to the newly created Arianespace, this did not change. Also, Arianespace was obliged to offer its services only in a non-military context, and as a French company, it was also controlled by France for the purposes of the relevant international commitments (first CoCom, then MTCR). ${ }^{39}$

Further proof that ESA was not to interfere in any way with national security concerns of its member states was found in a clause on sensitive information. In spite of a general obligation to "facilitate the exchange of scientific and technical information pertaining to the fields of space research and technology and their space applications" in the context of ESA programs, "a Member State shall not be required to communicate any information obtained outside the Agency if it considers that such communication would be inconsistent with the interests of its own security or its own agreements with third parties, or the conditions under which such information has been obtained." 40 Additionally, any transfer of "technology and products developed under the activities of the Agency or with its help" outside of the member states should be subject to a regime indicating when such transfers could be authorized, "bearing in mind the peaceful purposes of the Agency." 41

Similarly to ESA, the EC/EU ${ }^{42}$ has always been formally supposed to limit its activities to those that do not involve defense and military issues. ${ }^{43}$ For the 
time being, to the extent they are to be discussed in the EU framework at all, defense and military issues are relegated to the Common Foreign and Security Policy (CFSP), the EU pillar established to deal with common foreign and security policy. The CFSP, however, is a straightforward intergovernmental construction. ${ }^{44}$ There is at best a marginal role for the European Commission in its context as supposed guardian of the overarching European interest. ${ }^{45}$ There is no role for the elaborate legislative, adjudicative, and enforcement jurisdiction for either the European Parliament, in addition to the Commission, or the European Court of Justice that was developed in the context of the EC Treaty. Thus, the cooperation under the CFSP can result in the "implementation of a joint action or a common position," but can never "relate to matters having military or defense implications"; those issues remain exclusively reserved for national governments to deal with as they see fit. ${ }^{46}$

In Europe, matters of international cooperation in the areas of defense and security had been, at least until the EU and the CFSP started to play a role in this context, dealt with in the context of $\mathrm{NATO}^{47}$ or the Western European Union (WEU) ${ }^{48}$ Interestingly enough, the WEU is now being integrated into the EU structures, albeit still as part of the intergovernmental CFSP. Moreover, such integration is a slow process. It started in 1999 with a first level of integration of WEU functions into the EU framework, has meanwhile led to the handing over of the WEU satellite center at Torrejon, Spain to become the EU Satellite Center, jointly with a European Institute of Security Studies in 2002; but, has not been finalized yet, and some even doubt whether it will be ever complete. ${ }^{49}$ The Treaty on European Union refers to the role of the WEU in somewhat ambiguous terms. Security policies in the context of the CFSP pillar "shall not prevent the development of closer cooperation between two or more Member States on a bilateral level, in the framework of the Western European Union (WEU) and NATO, provided such cooperation does not run counter to or impede that provided for [through the CFSP]." ${ }^{50}$

The paradigmatic axiom that neither ESA nor the EU was supposed to touch upon any issues concerning defense and security has become subject to gradual erosion recently. This has come about in a rather indirect manner, in view of the statutory limitations resting upon both organizations to stay away from clearly military and defense-related matters. It can largely be contributed to, or was at least is very much reflected by, two major Europeanwide initiatives in space. In both cases, the Commission, representing the EU in this context, took the political, then also institutional and legal, lead, and ESA was duly entrusted with the technical and operational setting-up of the two space systems concerned-both, of necessity, with the more or less endorsement of the respective member states.

The first space project is Galileo, the envisaged satellite timing, positioning, and navigation system under exclusively European control, for which the 
Commission since 1994 had started to draft, then got accepted EC-level legislation providing a solid legal basis for the project. ${ }^{51}$ With the acceptance by EU and ESA member states of the full spectrum of envisaged services to be delivered by Galileo, the interpretation of "exclusively peaceful purposes" has been allowed to shift. Under the current, broader interpretation, involvement in security issues, at least as long as of a purely defensive nature, alternatively being sanctioned at the United Nations (UN) level, is now considered possible. ${ }^{52}$

A sort of precursor to this issue arose in the case of the intergovernmental satellite organization INMARSAT that is comprised of most European states as member states. Under its statutory documents, INMARSAT was obliged to comply with the mandatory requirement that all its activities were to be for "exclusively peaceful purposes." 53 Consequently, the question arose whether INMARSAT was entitled to offer its services in the context of the UN-sanctioned operations in Iraq in 1991. ${ }^{54}$ Interestingly, when INMARSAT was privatized in 1999, so as to evolve into a private operator, Inmarsat supervised by a residual intergovernmental International Mobile Satellite Organization (IMSO), this obligation continued to apply. ${ }^{55}$

The second major European space project concerns Global Monitoring for Environment and Security (GMES). ${ }^{56}$ This initiative, decided upon principally in 2001, is envisaged to become the pan-European contribution to the Global Earth Observation System of Systems (GEOSS), representing a global effort to enhance environmental protection with the help of satellite technology, with a view to the "E" of Environment. GMES also contains explicitly the " $S$ " of Security, which gradually came to be interpreted in a wide sense, beyond the more politically safe concept of "civil security" to encompass the more traditional, military and defense issues involved in security.

This then (Galileo and GMES), was the political climate in which it turned out to be possible for the European Commission to carefully push for and realize EC-wide legislation on the more specific security-focused issue of control of trade in sensitive technology. In doing so, it would back-up the MTCR and the Wassenaar Arrangement with a more solid and coherent legally binding regime on a European level.

\section{The Baseline Framework for a European Regime}

The current legal regime in the context of the EU, with respect to dual-use goods, technology, and expertise in terms of export controls, was developed based on Regulation 1334/2000.57 In many ways, this Regulation presents a follow-up specifically for the EU and its member states to the international regimes discussed above: a transformation thereof for the control of exports of dual-use items and technology into binding law for the EU itself and its member states. 
This becomes rapidly clear upon closer analysis of Regulation 1334/2000. The main aims of the Regulation are to develop an "effective common system of export controls on dual-use items [which] is necessary to ensure ... the international commitments and responsibilities of the Member States, especially regarding non-proliferation, and of the European Union," through "a common control system and harmonized policies for enforcement and monitoring." 58 It should be noted that this is considered, amongst others, "a prerequisite for establishing the free movement of dual-use items inside the Community," which is the most fundamental justification for EU institutions to address the issue of international trade in dual-use goods in the first place. ${ }^{59}$

Furthermore, the Regulation's Annex I, containing the List of Dual-Use Items and Technology that provides the substance of the regime, states in this respect "This list implements internationally agreed dual-use controls, including the Wassenaar Arrangement, the Missile Technology Control Regime (MTCR), the Nuclear Suppliers' Group (NSG), the Australia Group, and the Chemical Weapons Convention (CWC)."60 The Australia Group concerns chemical and biological weapons, and therefore, would not likely lead to insertions into the Regulation's regime relevant from the perspective of space activities, as is the case with the NSG and the CWC. Of course, as already indicated, this is different for the MTCR and Wassenaar Arrangement.

Regulation 1334/ 2000 has been amended on average almost once a year since by instruments of EC law, but still remains the key document in the present context. The main body of the Regulation sets up the basic regime; the Annexes through their updates take account of new developments regarding the subject matter itself. In particular Annex I, listing the dual-use items and technology, which were subject to the regime created by the Regulation, was amended time and again to keep track of ongoing technical developments as they also were leading to updates under the Wassenaar Arrangement in particular.

In terms of the scope of the regime established by Regulation 1334/2000, dual-use items are broadly defined as all "items, including software and technology, which can be used for both civil and military purposes, ${ }^{\prime 61}$ whereas export comprises "normal" export of goods, but extends to "transmission of software or technology by electronic media, fax, or telephone to a destination outside the Community," ${ }^{62}$ and "exporter" is equally broadly defined. ${ }^{63}$ Such a definition of dual-use items clearly could encompass more or less all space technology, and with "export of technology" already being at issue in the mere case of exchange of information by means of fax or telephone, the broad sweep of - as with the application of ITAR in the U.S. - the European regime becomes clear.

"Technology" itself is also defined in such broad terms, albeit not in the main body of the Regulation itself, but by Annex I; "specific information necessary for the development, production, or use of goods," further elaborated in that "this information takes the form of technical data or technical assis- 
tance," whereby the latter "may take forms such as instructions, skills, training, working knowledge, and consulting services, and may involve the transfer of technical data," and these may, in turn, "take forms such as blueprints, plans, diagrams, models, formulae, tables, engineering designs and specifications, manuals, and instructions, written or recorded, on other media or devices, such as disk, tape, and read-only memories." 64

\section{Follow-Up Regulations}

The clause quoted last does not come from Regulation 1334/2000 itself, but from an instrument of EC law following up on its substantive details. Such substance of those follow-up instruments, dealing with such issues as the items subject to export controls under it, as well as the authorization framework following from the complex structure of categorization of these items, will be discussed later. First, the general structure of the regime built upon Regulation 1334/2000 will be addressed.

As already indicated, Regulation 1334/2000, in particular the List of DualUse Items and Technology as contained in Annexes I and IV, which will be dealt with below, was established in such a way as to take into account relevant changes in technical developments, preponderantly those reflected by the international regime of the Wassenaar Arrangement referred to earlier. Thus, Chapter IV of the Regulation specifically provides that "the lists of dual-use items set out in Annex I and Annex IV shall be updated in conformity with the relevant obligations and commitments, and any modification thereof, that each Member State has accepted as a member of the international non-proliferation regimes and export control arrangements, or by ratification of relevant international treaties." 65

This concerns, in particular, the following regulations, taking care of a more or less annual update, especially of the relevant Annexes:

- Regulation 2889/2000, providing for minor changes to Annexes I and IV; $; 6$

- Regulation 458/2001, providing for minor changes to Annex I; ${ }^{67}$

- Regulation 2432/2001, providing for updates to, and replacement of, the Annexes to take account of, inter alia, changes adopted by the Wassenaar Arrangement plenary session in December 2000;68

- Regulation 880/2002, providing for minor changes to Annex IV; ${ }^{69}$

- Regulation 149/2003, providing for updates to, and replacement of, the Annexes to take account of, inter alia, changes adopted in the context of the Wassenaar Arrangement's regime in the course of 2001 and 2002; ${ }^{70}$

- Regulation 885/2004, ensuring application of a number of EC Regulations and Decisions including Regulation 1334/2000 to the ten then-new EU member states; ${ }^{71}$

- Regulation 1504/2004, providing for updates to, and replacement of, the 
Annexes to take account of, inter alia, changes adopted in the context of the Wassenaar Arrangement's regime between December 2002 and December 2003,72

- Regulation 394/2006, providing for updates to, and replacement of, the Annexes to take account of, inter alia, changes adopted in the context of the Wassenaar Arrangement's regime; ${ }^{73}$

- Regulation 1183/2007, providing for updates to, and replacement of, the Annexes to take account of, inter alia, changes adopted in the context of the Wassenaar Arrangement's regime; ${ }^{74}$ and

- Regulation 1167/2008, providing for updates to, and replacement of, the Annexes to take account of, inter alia, changes adopted in the context of the Wassenaar Arrangement's regime. ${ }^{75}$

Since, so far, Regulation 1167/2008 constitutes the latest updates of Annexes I and IV, reference will be had to those latest versions wherever appropriate. This brings the analysis to the issue of the substance of these Annexes, as these determine to a great extent the application of the two-pronged authorization structure under the Regulation regime.

\section{The Annexes: Providing the Technical Substance}

The technical substance of the European export control regime is provided by a complicated interplay of three Annexes: (1) Annex I provides the bulk of the items; (2) Annex II provides a list of certain items excepted from the standard consequences of being included in Annex I; and (3) Annex II includes a separate Annex IV for control over additional items.

Further to Article 3 of Regulation 1334/2000, it is in the first place Annex I, entitled the "List of Dual-Use Items and Technology," which "implements internationally agreed dual-use controls including the Wassenaar Arrangement [and] the Missile Technology Control Regime (MTCR)." ${ }^{76}$ Interestingly, compared to the previous version as per Regulation 1183/2007, the Annex now no longer includes a specific reference to the possibility that individual member states might have additional prohibitions in place, which would continue to be valid: "No account has been taken of any items that Member States wish to place on an exclusion list. No account has been taken of any national controls (non-regime origin controls) that may be maintained by Member States."77

Annex I contains introductory statements and a list of definitions of terms. The most important of those is the aforementioned broad definition of "technology" for the purpose of the Regulation. Exceptions to the application of the Regulation as far as technology is concerned apply to "information in the public domain, to basic scientific research, or to the minimum necessary information for patent applications." 78 Especially, the first and third exceptions may be of key importance for the commercial/civil space sector to the extent the international activities involve a transfer of off-the-shelf technology 
(equivalent here to being "in the public domain"), or a transfer of technical information that is unavoidable if an invention is to be protected. This does not imply that such transfers ipso facto are allowed, or otherwise go uncontrolled. The relevant national authorities now have the freedom, in the absence of obligations under the EC regime, to decide on limiting such transfers, as long as this occurs in conformity with certain secondary requirements imposed by Regulation 1334/2000 relating to justification of the limitations, as well as, informing other stakeholders in the European regime. ${ }^{79}$

The reference to non-applied scientific research, excepting it from the scope of the regime here, is to be noted. The focus of the EC-law regime is clearly on the commercial aspects, where there would only be secondary attention for basic scientific research, rather than on establishing a level of control that takes Europe's security concerns directly into consideration. This is in line with general EC-law concerns for an Internal Market and a level playing field for commercial ventures throughout the EU; the main concern here is to have similar, equivalent, or equal requirements, not to arrive at either strict or relaxed requirements as such.

Definitions that result in likely implications for many European space projects, including Galileo and GMES, and many more commercial satellite communication or remote sensing activities, are "cryptography," 80 "digital computer," 81 "hybrid computer," 82 "information security," 83 "main storage," 84 "microcomputer microcircuit," 85 "microprocessor microcircuit,"86 "multidata-stream processing," 87 "network access controller," 88 "program," 89 "real time processing," 90 "software," 91 "source code," 92 "tape," 93 and "spacecraft," meaning "active and passive satellites and space probes." 94 The main body of Annex I consists of the List itself, divided into ten categories. Amongst those, Categories 0 (nuclear materials, facilities, and equipment), 1 (materials, chemicals, "microorganisms," and "toxins"), 2 (materials processing), and 8 (marine), would not directly seem to be relevant for many space activities at issue in the present analysis, especially not when focusing upon commercial space. ${ }^{95}$ The relevant Categories are discussed next.

\section{Electronics}

Category 3 is entitled "Electronics" and is further subdivided as follows: ${ }^{96}$

- Systems, equipment, and components, dealing essentially with relevant hardware;

- Test, inspection, and production equipment, equally dealing with relevant hardware;

- Materials, concerning the physical materials that could be used for producing certain relevant hardware and other products;

- Software, which focuses on software designed for developing or producing equipment under the first bullet point above, but also includes simu- 
lation software, especially designed for the development of lithographic, etching, or deposition processes for translating masking patterns into specific topographical patterns in conductors, dielectrics, or semiconductor materials; 97 and

- Technology, which includes technology for the development or production of a microprocessor microcircuit, or microcomputer microcircuit and microcontroller microcircuit core. ${ }^{98}$

As space activities in general, including also commercial space activities, are a high-key technological sector, inevitably a major amount of electronic systems, software, and technological know-how will be involved, which may come within the scope of the regime. Hence, the operators undertaking those activities might benefit from the European transparency, to some extent even de facto harmonization, resulting from the authorization structure discussed further below, making it at least less cumbersome to comply with any requirements concerned.

\section{Computers}

Category 4 is entitled "Computers" and lists the following controls: ${ }^{99}$

- Systems, equipment, and components, dealing essentially with relevant hardware, such as digital computers, electronic assemblies, and processors;

- Software, including operating system software, and software development tools and compilers, especially designed for multi-data-stream processing equipment, in source code; ${ }^{100}$ and

- Technology, essentially for the purpose of development, production or use of any of the above.

Once again, the involvement of computers in space activities is evident and comprehensive. It does not only involve systems, components, and software part of a spacecraft to be transported outside the member states of the EU, for instance for purposes of the launch, but also such systems, components and software as are to be exported to third countries for ground stations.

\section{Telecommunications and Information Security}

Category 5 is entitled "Telecommunications and Information Security."101 The relevant controls, include:

- Part 1-Telecommunications, containing:

o Systems, equipment, and components, focusing on relevant hardware involved in telecommunications, both wireless and wired, enjoying special physical protection against interference or generally of high quality;

o Test, inspection, and production equipment with a view to the 
above subcategory;

o Software for any of the above; and

o Technology, essentially for the purpose of development, production, or use of any of the above, broadly defined to possibly include technology for the development of telecommunications in the service of data generation, production, and generation. ${ }^{102}$

- Part 2-Information Security, ${ }^{103}$ containing:

o Systems, equipment, and components, dealing with all hardware relevant for information security purposes, including cryptography and digital techniques;

o Test, inspection, and production equipment with a view to the above subcategory;

o Software for any of the above, including for development, production, use, and support thereof; and

o Technology, essentially for the purpose of development, production, or use of any of the above.

The application of the items in Part 1 may seem limited to the satellite communications sector only, but this would ignore the fact that for instance remote sensing satellites, navigation satellites, and space stations need a certain amount of communication capability to function as planned. Part 2 is more refined in its de facto applicability to the space sector. Apart from military communications, which do not fall in principle under the EC-law regime, especially in certain satellite navigation services or Earth observation activities the use of cryptography would bring those activities easily within the scope of this particular heading.

\section{Sensors and Lasers}

Category 6 is entitled "Sensors and Lasers" and is further subdivided as follows: ${ }^{104}$

- $\quad$ Systems, equipment, and components, including in particular:

o Optical sensors, such as various categories of space-qualified, solid-state detectors, non-space-qualified, focal plane arrays, mono-spectral imaging sensors, multispectral imaging sensors designed for remote sensing applications, and special components for optical sensors; ${ }^{105}$

o Cameras with certain characteristics as specified;

o Optics, including those components that are space-qualified; 106 and

o Radar systems, equipment, and assemblies with certain characteristics as specified.

- Test, inspection, and production equipment, especially with regard to optical equipment; 107 
- Materials of a certain nature inter alia for producing optical equipment;,;08

- Software for any of the above; and

- Technology, essentially for the purpose of development, production or use of any of the above.

As to the scope of the regime from a space-vantage point, many remote sensing activities, whether GMES-related or commercial/civil, would be impacted. Notably, both "mono-spectral imaging sensors," i.e., sensors that "are capable of acquisition of imaging data from one discrete spectral band,"109 and "multispectral imaging sensors," i.e., sensors that "are capable of simultaneous or serial acquisition of imaging data from two or more discrete spectral bands,"110 are included in the list of definitions, and fall within the regime under consideration.

\section{Navigation and Avionics}

Category 7 is entitled "Navigation and Avionics" and is further subdivided as shown below: ${ }^{111}$

- Systems, equipment, and components, including notably:

o Global navigation satellite systems receiving equipment, and specially designed components, employing decryption or a nullsteerable antenna, including if designed or modified for use in space launch vehicles and sounding rockets, ${ }^{112}$ but also:

o Inertial systems and their components, including if designed for spacecraft; $; 13$

o Gyro-astro compasses and similar devices, including if tracking satellites for their purposes; ${ }^{114}$ and

o Guidance sets usable in missiles of a certain minimum accuracy. ${ }^{115}$

- Test, inspection, and production equipment specifically involved in testing, inspecting, or producing any of the systems, equipment, or components mentioned under the above subcategory;

- Software designed for any of the above; and

- Technology, following the general definition and as far as involved in any of the above, including for instance for the integration of the flight control, guidance, and propulsion data into a flight management system for optimization of rocket system trajectory. ${ }^{116}$

This category is of key importance for satellite navigation. While the systems themselves, i.e., the U.S. Global Positioning System (GPS), the Russian GLONASS, Galileo, and others (China, Japan, and India, for example, have plans for systems) for obvious reasons are not subject to the regime, most aspects of downstream usage, focusing on receivers and the technology behind them, are. In fact, this Category makes specific reference to GPS and GLONASS as current versions of such systems. The key caveat herein is that 
only receivers employing either encryption techniques or null-steerable antennae are subject to the harmonization regime, which causes a major portion of global navigation satellite systems devices to fall outside the scope thereof.

Once more, it should be noted that the difference between falling within its scope or remaining outside thereof, is not a difference between exports thereof being controlled or not. The difference, by contrast, is solely between such export being controlled according to certain EU-wide requirements still leaving the ultimate decision to allow export or not in national sovereign hands, and such export completely being a matter of national discretion, including the option not to control it altogether, subject only to being properly justified.

\section{Aerospace and Propulsion}

Finally, Category 9, entitled "Aerospace and Propulsion" entails the following controls: ${ }^{117}$

- Systems, equipment, and components, including for example such devices as space launch vehicles and spacecraft; liquid rocket propulsion systems using a circumscribed array of components as well as engines involved; solid rocket propulsion systems and engines, including relevant components; hybrid rocket propulsion systems, engines and their components; sounding rockets and individual rocket stages as long as capable of a range of at least $300 \mathrm{~km}$ [kilometers]; re-entry vehicles and even liquid propellant tanks used for rockets with the capability of delivering at least a $500 \mathrm{~kg}$ [kilograms] payload to a range of at least $300 \mathrm{~km} ;{ }^{118}$

- Test, inspection, and production equipment, basically again as involved in testing, inspecting, and producing any of the above, including acoustic vibration test equipment of a certain minimum capability; ${ }^{119}$

- Materials, such as insulation material in bulk form and interior lining for rocket motor cases usable in missiles; ${ }^{120}$

- Software specifically developed for much of the above; and

- Technology, again as relevant for any of the above.

This category applies to launcher development and manufacturing and launch service provisions, and it represents the core element of the MTCR regime in the European context. The direct relevance of this Category is to launcher hardware, software, and technology for security considerations; these considerations in the area of satellite navigation are much more of an indirect nature. As a consequence, the list of items to be controlled at a European level, or at least under European coordination and transparency mechanisms, in the present Category is quite comprehensively drafted. 


\section{Other Controls}

As indicated, Annex II $^{121}$ inter alia provides for a list of items excepted from the standard consequences of being included in Annex I. ${ }^{122}$ Annex II refers to items specified in Annex IV, and further explicitly lists a limited number of items, of which there are three of interest in the context of space activities. All these items are presumably too sensitive to leave them to be regulated under a common authorization, as opposed to being controlled by the individual sovereign member states of the EU.

The three specified items of relevance concern:

1. "technology for the integration of the flight control, guidance, and propulsion data into a flight management system for optimization of rocket system trajectory;"

2. "hybrid rocket propulsion systems with total impulse capacity exceeding 1.1 MNs [meganewtons];"124 and

3. "staging mechanisms, separation mechanisms, and interstages, usable in missiles." 125

Annex IV provides a list of items concluded in the main list of Annex I considered so sensitive that (in deviation from the general thrust of the Regulation to allow for transfers of items within the EU) even such intra-community transfers of these items are made subject of an obligation to obtain an authorization. ${ }^{126}$ With a view to what authorizations would be available, Annex IV is divided into two parts, of which Part II is not relevant in the present context as it deals with items related to international controls under the Chemical Weapons Convention or the Nuclear Suppliers' Group arrangements. ${ }^{127}$ Of such items, with a view to the categories of Annex I and those deemed to be of relevance for space activities, Part I deals with broad categories of stealth technology, strategic control, and MTCR technology. Here, some items may be specifically mentioned with regard to space activities.

The subcategory of items of stealth technology encompasses two items of Category 6, of which "systems specially designed for radar cross-section measurement usable for missile and their subsystems" should be noted here. ${ }^{128}$ In the subcategory relevant for Community Strategic Control issues, the main set of items currently relevant equally refers to Category 6 items, including items for acoustics, plus a few items relating to noise reduction under Category 8. A further subset is recognized within this subcategory, of "Items of the Community Strategic Control-Cryptography-category 5 Part 2," which may be relevant for space activities in a broad sense. ${ }^{129}$

Finally, the subcategory of MTCR technology items contains an extend list of items belonging to Categories 7 and 9. They include: "Guidance sets, usable in missiles, capable of achieving system accuracy of $3.33 \%$ or less of the range ... except guidance sets designed for missiles with a range under $300 \mathrm{~km}$;"130 
"Space launch vehicles capable of delivering at least a $500 \mathrm{~kg}$ payload to a range of at least $300 \mathrm{~km} ;{ }^{\prime \prime 131}$ sounding rockets with the same capability; ${ }^{132}$ individual rocket stages if usable for rocket systems with the same capability; ${ }^{133}$ rocket engines, systems, or components usable in missiles; ${ }^{134}$ re-entry vehicles except if "designed for non-weapon payloads;" tion equipment, software items, and technologies for any of the above. ${ }^{136}$

The extent to which this subcategory of MTCR items has the potential to stifle non-military or security-related space activities is reflected in four additional provisions. These provide that the controls under this heading are not applied to items

1. that are transferred on the basis of orders pursuant to a contractual relationship placed by the European Space Agency (ESA) or that are transferred by ESA to accomplish its official tasks; 2 . that are transferred on the basis of orders pursuant to a contractual relationship placed by a Member State's national space organisation or that are transferred by it to accomplish its official tasks; 3 . that are transferred on the basis of orders pursuant to a contractual relationship placed in connection with a Community space launch development and production programme signed by two or more European governments; and 4. that are transferred to a State-controlled space launching site in the territory of a Member State, unless that Member State controls such transfers within the terms of this Regulation. ${ }^{137}$

In those four cases, the control inherently exercised by ESA, the main EU organs, and the governments concerned is considered adequate, at least sufficiently so not to require further controls under Regulation 1334/2000 to be put in the way of efficiently conducting the civil space activities concerned.

This is a rather complicated set up, as Annex I includes a very extended baseline list of items but Annexes II and IV, each for their own purposes, carve out some especially sensitive items. The main reason behind this set-up lies in the specific consequences to be attached to the various categories, subcategories, and exceptional categories under the authorization framework developed by Regulation 1334/2000. This is analyzed next.

\section{The Authorization Regime}

Ultimately, the regime functions based on the authorization aspects as established by Regulation 1334/2000. Authorization is required for export of the dual-use items listed in Annex I, taking the Wassenaar Arrangement's List of Dual-Use Goods and Technologies as point of departure, augmented as relevant by controlled goods and technologies under, amongst others, the MTCR. ${ }^{138}$ The obligations of a prospective exporter are not limited to screening an exhaustive list and then abiding by its terms. There are three scenarios under which such an exporter would be obliged to comply with the control and authorization mechanisms provided by the Regulation, also where 
the items concerned as such are not listed in Annex I, or Annexes II and IV, as they deal in more detail with specific parts thereof.

Under the first scenario, the exporter is informed by competent EU member state authorities that such an item might become involved in developing, producing, or otherwise handling weapons of mass destruction in contravention of the Regulation's aims and purposes. ${ }^{139}$ The same obligation pertains if the exporter himself has become aware of such an involvement. ${ }^{140}$

Under the second scenario, export is at issue to a "purchasing country or country of destination," 141 which happens to be subject to an arms embargo that is the result of appropriate decision-making within either the Council of the European Union, ${ }^{142}$ the Organization for Security and Cooperation in Europe (OSCE), ${ }^{143}$ or the UN Security Council. ${ }^{144}$

Under the third scenario, the export would concern items that "are or may be intended, in their entirety or in part, for use as parts or components of military items listed in the national military list that have been exported from the territory of that Member State without authorization or in violation of an authorization prescribed by national legislation of that Member State." 145 Here, the need for harmonization at the EU level for the purpose of enhancing trade in dual-use issues as long as not security-sensitive gives way to the individual sovereign rights of the member states. These states remain specifically entitled to determine their preferred level of security above and beyond that determined to be generally applicable under the Regulation's regime-albeit, that such higher member state thresholds are only allowed "for reasons of public security or human rights considerations," and require the member state in question to immediately inform the Commission. ${ }^{146}$

That sovereignty is still the underlying current in this area is also evidenced by another clause. This clause establishes the possibility for a prospective exporter to be confronted with requirements for authorizations imposed by member states under national laws and regulations outside of the system of the Regulation properly speaking, as outlined above. ${ }^{147}$ In such cases, the Regulation only imposes upon the member state adopting or maintaining such relevant legislation a duty to inform other member states as well as the Commission. ${ }^{148}$

\section{The Community General Export Authorization}

Authorizations under the Regulation's regime can be of two principled kinds. The starting point, the main reason for developing a control regime at the European-level in the first place, is a Community General Export Authorization (CGEA), which was established by Regulation 1334/2000. ${ }^{149}$ The CGEA explicitly constitutes an exception to the sovereign discretion of member states referred to earlier; it formally confirms that for all other items, that is those not covered by it, any authorization shall be granted, or refused, by the member 
state where the exporter is located. ${ }^{150}$ It is, consequently, the scope of the CGEA, which is further defined through the complex interplay between Annexes I, II, and IV. That scope is essentially limited in two ways relative to the scope of the general authorization obligation under the Regulation as discussed above.

First, ratione materiae only items as defined by Annex I-with the exception of those mentioned in Part 2 thereof - require the CGEA, as opposed to a national authorization. ${ }^{151}$ As can be glanced from the previous overview of Annex I, this actually covers the bulk of controlled items listed under the Regime. Second, ratione personae the CGEA covers such exports only to the extent the target destination is Australia, Canada, Japan, New Zealand, Norway, Switzerland, or the U.S. ${ }^{152}$ In other words, with respect to some key allies in the context of NATO and the Wassenaar Arrangement, as well as the two ESA member states that are not members of the EU, individual national security sensitivities are not considered to be put at risk by any harmonization at a European level.

Further exceptions to applicability of the CGEA occur in three more limited scenarios dealt with in Annex II as far as items not covered by Annex I are concerned. In the first exception, either the exporter has been informed by the competent authorities of the EU member state in which he is established that the items in question are crucially involved with weapons of mass destruction, or he has otherwise become aware that the items in question are intended for such use. ${ }^{153}$ This is a rather straightforward exception, dealing with cases where national, and international, security is considered threatened too directly for any authorization to take place. In principle, it may be relevant for some cases involving space related technology.

The second case is where the items in question are destined for a state subject to an EU, OSCE, or UN arms embargo, or if the exporter is aware that the items in question are intended for such use. ${ }^{154}$ This clause is to honor obligations undertaken either in the context of the EU's political machinery itself, or within the two broader organizations mentioned, with regard to measures internationally agreed to counter threats to international peace and security, and those obligations cannot be allowed to be undercut somehow by application of the CGEA.

The third case deals with a separate issue. The CGEA cannot be called upon to authorize exports in case the relevant items are to be exported to a destination within a customs free zone or free warehouse. ${ }^{155}$ If such exports were to be allowed, the possibility to control onward export to states to which they should not be exported is thwarted. This case defies the controls the CGEA seeks to apply.

\section{National Authorization}

The delineations of the scope of application of the CGEA in various ways, means that as if by default, in other cases the national member states maintain 
their sovereign discretion to apply domestic controls. The final responsibility for deciding on applications for export authorizations, outside the scope of the CGEA, lies with the national authorities of the EU member states. ${ }^{156}$ Consequently, the competent authorities may refuse to grant an export authorization and may annul, suspend, modify, or revoke an export authorization that they have already granted. ${ }^{157}$

To begin with, this concerns cases where the CGEA would not apply because one of the three scenarios referred to above is applicable (involvement in a context of weapons of mass destruction, export to a state under a relevant embargo, or to a free zone or free warehouse). This would apply, however, in spite of the items being concerned ratione materiae falling within the scope of Annex II. Next, domestic controls continue to apply for any export of items in Annex I, ratione personae, to states other than EU member states or the limited group of states mentioned in Annex II: Australia, Canada, Japan, New Zealand, Norway, Switzerland, and the U.S. Third, as discussed, they apply to items specifically mentioned by Annex II, which includes the complete list provided in Annex IV. Lastly, they apply to any items not listed altogether in the Annexes to the Regulation. Following from the underlying sovereigntydominated logic, EU member states may also in their discretion decide to "prohibit or impose an authorization requirement" regarding items not listed in Annex I as long as such controls are justified on the grounds of public security or human rights considerations, and such states "notify any measures adopted pursuant" to this clause to the Commission. ${ }^{158}$

A national authorization may generally be of three kinds: individual; global; or general, valid throughout the Community. ${ }^{159}$ While leaving the choice to the national member state authorities, regarding which type of authorization to use in a certain case, a few specific limits are imposed by the Regulation in that regard. In any event, when deciding upon the grant of a national authorization, an EU member state shall take into account international obligations and commitments, such as those under the MTCR, Wassenaar Arrangement, internationally agreed sanctions as applicable, and considerations of national and foreign security policy, including such as following from the European Union Code of Conduct on arms exports, intended end-uses, and risks of diversion. ${ }^{160}$

As to individual authorizations, to be applied on a case-by-case basis, the Regulation imposes one main caveat in relation to the sovereign discretion of an EU member state. Such a state, if requested for such an authorization, is required to consult with other member states in every case where the items for which the authorization is requested are present in such other member states. ${ }^{161}$ As to the global authorizations, the approach taken here is to cover a type or category of items in a more general fashion, and allow the export of any items falling within its scope to one or more specified states. ${ }^{162}$

For general authorization the approach is the same as under the CGEA, only this time on a national level; a list is issued where the presumption is 
that export is authorized unless specific reasons inform against this. ${ }^{163}$ Such reasons refer to cases where the exporter either is informed by relevant authorities or has become aware himself that the items in question are, or may be, intended for use in the context of weapons of mass destruction, in contravention of an arms embargo following from EU Council, OSCE, or UN Security Council decisions, or for use ultimately in contravention of the national export controls of the member state concerned. ${ }^{164}$

Items listed in Annex II - which, as analyzed, include also the items listed in Annex I-as such may not be included in a general authorization; such items require the more targeted approach of an individual or global authorization being applied. ${ }^{165}$ The exception here is the list of items listed in Annex IV, but only as far as intra-Community trade is concerned; in those cases (comprising of stealth technology, and strategic control items, including cryptography items and MTCR technology), use of a national general authorization is allowed. ${ }^{166}$

\section{Conclusions}

In Europe, the issue of controlling the export of military and dual-use technology is considered a crucial aspect of national security of the individual European states. Absent an ingrained supranational system for dealing with security issues (not even the EU as of now has been able to establish an autonomous position in that field beyond the intergovernmental CFSP), the individual sovereignty of those states remains preeminent in regulating such exports.

Nevertheless, amongst key European states a clear need for moving beyond the levels of transparency, consultation, and coordination already offered by international, non-binding regimes, such as the MTCR and the Wassenaar Arrangement, has been apparent for roughly a decade. This development was linked to a realization that if Europe should take a more proactive role in that area for the benefit of all concerned, a certain level of harmonization would be indispensable.

The first result is Regulation 1334/2000, which in conjunction with followup Regulations (most recently, Regulation 1167/2008) created a complex interlocking system of European-wide and national authorizations. That system required such authorizations in varying measures for the export of the items listed in a few interlocking Annexes to other EU member states, a limited set of close political allies respectively, and other states and destinations.

For many readers, this will raise the question whether that system has been able to avoid the pitfalls of, notably, the U.S. system. The main point here concerns the balance between security interests and commercial/industrial interests, where most criticism directed at ITAR concern the perception that the balance has tilted far too much towards the security interests. The commercial space industry (primarily, but not exclusively the U.S. one), even 
if it is not security sensitive, consequently finds itself considerably obstructed in its international cooperation, marketing, and sales activities. How comprehensive then is the EC regime from such a comparative perspective?

The major novelty established by the EC-law regime based upon Regulation 1334/2000 is the establishment of the CGEA, as the most outspoken effort to arrive at a standardization and simplification of licensing procedures for export. The CGEA constitutes a semi-automatic European-wide authorization for exports of dual-use items. The most sensitive items (such as any items involved in the development, production, or handling of weapons of mass destruction), however, remain under various national controls. The requirements imposed by the regime in this regard only posit obligations related to information and consultation, wherever relevant.

Still, the CGEA is seen as an important step towards a coherent European export control regime. It deals ratione materiae with the bulk of items possibly requiring export controls, including those as following from various sets of international obligations (from MTCR and Wassenaar Arrangement, to OSCE and UN sanctions) by means of Annex I. It only allows for a relatively limited set of exceptions, following inter alia from Annexes II and IV. Ratione personae, the limitations of this harmonizing step are considerably more limited since only intra-Community trade and trade with a handful of close allies are falling within the CGEA's scope.

The relative flexibility of the structure under Regulation 1334/2000 and its later additions, through the mechanism of the Annexes allowing for continuous updating, ensures the latest relevant developments are appropriately taken into consideration. This, of course, refers to the discourse on the international and global level of non-proliferation and export controls, and, in particular, how it impacts the space arena; MTCR, the Wassenaar Arrangement, and for that matter the U.S. ITAR, as they have a major impact on the international arena, are subject to the changing realities in the world at large.

From this perspective, the CGEA also presents another interesting novelty. MTCR and the Wassenaar Arrangement are voluntary regimes. By contrast, the EU regime, and the CGEA in particular, for all its complexities and deference to state sovereignty, reflect the willingness of a group of like-minded states to subject themselves to a system of international controls. Even if as of yet this does not concern the most sensitive areas, and even as these states collectively at least are still controlling any new extensions of the scope of the regime (notably through their membership on the EU Council and the intergovernmental nature of the CFSP, which basically requires unanimity and allows non-agreeing states to opt out), this is not a negligible achievement.

The reason is, at least in part, the indirect approach taken by the Commission. It does not focus as such on the issue of controls, but on the distorting effects on the Internal Market that result from widely divergent levels of con- 
trol on the export of certain goods or services. From that perspective, there is no fundamental difference between bananas, banking services, and bomb-carrying missiles. As long as they are objects of economic trade and transactions, any conditions, limits, and requirements imposed upon their export should be harmonized throughout the EU to create such an Internal Market and preclude license shopping for the most lax regime. In addition, from that perspective, the nature of such conditions, limits, and requirements is of secondary importance only. Whether of a monetary nature (export or import tariffs), of a quantitative nature (export or import quota), or of an administrative nature (guarantees that certain onward exports or certain usage in the context of weapons of mass destruction are precluded), they should be applied equally across the EU member states in order to maintain a level playing field.

Put differently, the fact that bomb-carrying missiles are different from bananas and banking services, and that guarantees as referred to are necessary and appropriate, should lead to appropriate levels of controls, not to different levels of controls, across the EU. While the EC-law regime, as the legal instrument involved, can preclude, at least in theory, the latter, achieving the former as such is not yet within its purview, but all the same is the hoped-for outcome of the application of that instrument.

In this context and with a view to international space cooperation and the international space industry in particular, two further contributions to the international discourse offered by the EC-law regime based upon Regulation 1334 / 2000 are particularly noteworthy. One, while the regime is far from simple, it at least avoids the conflicts between two entities responsible for, respectively, the core issue of delivery systems for weapons of mass destruction and the broader issue of sensitive dual-use technology. The domestic situation in the U.S., with AECA/Department of State/USML/ITAR often pitted against EAA/Department of Commerce/CCL/EAR, with items moving back and forth and with prospective exporters often wondering where their particular item might fit in, is thus largely avoided in Europe. As mentioned, this situation has largely been reflected on the international level, although, the MTCR and the Wassenaar Arrangement avoided many of these practical problems from arising by default, because of the legally non-binding character of both regimes. The EC-law regime, by contrast, comprises the two in one regime, while adding the other international non-proliferation regimes stemming from NSG, the Australia Group, and the CWC.

Two, as mentioned, a clear-cut set of exceptions to the non-applicability of the harmonizing effects of the EC-law regime to MTCR technology items as listed in Annex IV is provided for. It applies in case such items are involved in civil or commercial space endeavors. These cases are defined as exports of items, if taking place in the context of ESA activities, activities of national space agencies (under the control, after all, of the national governments), activities under the sway of the EU, activities undertaken in the context of in- 
ternational cooperation between two or more EU member states, or activities otherwise falling within the control of an EU member state. No authorization is indeed made applicable to any such items if the exports take place within the Union, whereas the CGEA applies to exports outside of the EU.

It is on those two accounts that the EC-law regime based on Regulation $1334 / 2000$, evolving as it is, represents an important contribution to building a globally transparent and balanced regime, taking into account both the justified security concerns of the states concerned and the commercial interests of the space industries in those countries, as part of their potential contributions to global peace and welfare. This, the more so in that the EC-law regime throughout rather faithfully follows the relevant definitions devised at the international level, instead of devising its own, new set of definitions, which already in itself considerably adds to the transparency and coherence. Business always benefits from transparency and coherence, in outer space as much as anywhere else does. But also, national and international security in the last resort is not helped by the existence of arcane, needlessly complicated, and non-transparent regimes as commercial entrepreneurs may not be the only ones interested in seeking out the loopholes and oversights inherently resulting from such controlling regimes.

\section{Notes}

1. Interesting discussions on these issues can be found in: Pamela L. Meredith and Sean P. Fleming, “U.S. Space Technology Exports: The Current Political Climate," Journal of Space Law 27 (1999): 3553; and Mike N. Gold, "Lost in Space: A Practitioner's First-Hand Perspective on Reforming the U.S.'s Obsolete, Arrogant, and Counterproductive Export Control Regime for Space-Related Systems and Technologies," Journal of Space Law 34 (2008): 163-185.

2. See Gold (note 1): 165.

3. On this, in a more general context, see the author's "As Space Law Comes to Nebraska, Space Comes Down to Earth," Nebraska Law Review 87 (2008): 500-505, 510.

4. United States Munitions List (USML), 22 C.F.R. 121, last revised 1 April 2008.

5. Arms Export Control Act of 1976, 22 U.S.C. 2751.

6. See Meredith and Fleming (note 1): 40-41. Note that the ITAR has existed since 1955.

7. See Meredith and Fleming (note 1): 41-42; and Gold (note 1): 171-172.

8. USML, 22 C.F.R., § 121.1, at p. 469. See further Meredith and Fleming (note 1): 44-45.

9. As Gold (note 1): 165, notes: "the U.S. had become the only nation that still treated commercial communication satellites as munitions."

10. Commerce Control List (CCL), 15 C.F.R. 774, last revised 1 January 2008.

11. See Meredith and Fleming (note 1): 38; and Gold (note 1): 165.

12. Export Administration Act of 1979, Public Law 96-72, 96th Congress, 93 Statue 503. This was the original version of the Act, amended a number of times since 1979.

13. See Meredith and Fleming (note 1): 38; and Gold (note 1): 165.

14. See Meredith and Fleming (note 1): 36-39; and Gold (note 1) 165-166.

15. Strom Thurmond National Defense Authorization Act for Fiscal Year 1999, Public Law 105-261, 105th Congress, 17 October 1998, 112 Statue 1920.

16. See Meredith and Fleming (note 1): 37-39; and Gold (note 1): 165-167.

17. USML, 22 C.F.R., $§ 121.1$, at pp. 481-482. See further Meredith and Fleming (note 1): 42-44.

18. See Meredith and Fleming (note 1): 50-51.

19. Thomas Gillon, “Regulating Remote Sensing Space Systems in Canada-New Legislation for a 
New Era," Journal of Space Law 34 (2008): 24; Bruce W. Mann, “First License Issued under Canada's Remote Sensing Satellite Legislation," Journal of Space Law 34 (2008): 73-74; and Meredith and Fleming (note 1): 52.

20. Agreement on Guidelines for the Transfer of Equipment and Technology Related to Missiles (hereafter, MTCR), done 16 April 1987, 26 ILM 599 (1987). See http://www.mtcr.info/english/index. $\underline{\mathrm{html}}$; also, see Elizabeth S. Waldrop, "Integration of Military and Civilian Space Assets: Legal and National Security Implications," Air Force Law Review 55 (2004): 189-190.

21. The original Agreement dealt with nuclear weapons only - the inclusion of chemical and biological weapons was achieved in 1993, with the Agreement on Guidelines for the Transfer of Equipment and Technology Related to Missiles as Amended, effective 7 January 1993, 32 ILM 1298 (1993).

22. The MTCR is currently adhered to by the following states (where appropriate, membership of the European Union (EU) and the European Space Agency (ESA) is indicated): Argentina, Australia, Austria (EU/ESA), Belgium (EU/ESA), Bulgaria (EU), Brazil, Canada, the Czech Republic (EU/ ESA), Denmark (EU/ESA), Finland (EU/ESA), France (EU/ESA), Germany (EU/ESA), Greece (EU/ESA), Hungary (EU), Iceland, Ireland (EU/ESA), Italy (EU/ESA), Japan, Luxembourg (EU/ ESA), Netherlands (EU/ESA), New Zealand, Norway (ESA), Poland (EU), Portugal (EU/ESA), Republic of Korea, Russian Federation, South Africa, Spain (EU/ESA), Sweden (EU/ESA), Switzerland (ESA), Turkey, Ukraine, the United Kingdom (EU/ESA), and the United States; 19 out of the current 27 EU member states-Cyprus, Estonia, Latvia, Lithuania, Malta, Romania, Slovakia and Slovenia are missing - and all 18 ESA member states are participating in the MTCR.

23. See http:/ / www.mtcr.info/english/guidetext.htm

24. See http://www.mtcr.info/english/annex.html

25. Wassenaar Arrangement on Export Controls for Conventional Arms and Dual-Use Goods and Technologies (hereafter, Wassenaar Arrangement), Wassenaar, completed 19 December 1995, effective 12 July 1996.

26. The Wassenaar Arrangement is currently adhered to by the following states (where appropriate, membership of EU and ESA is indicated): Argentina, Australia, Austria (EU/ESA), Belgium (EU/ ESA), Bulgaria (EU), Canada, Croatia, the Czech Republic (EU/ESA), Denmark (EU/ESA), Estonia (EU), Finland (EU/ESA), France (EU/ESA), Germany (EU/ESA), Greece (EU/ESA), Hungary (EU), Ireland (EU/ESA), Italy (EU/ESA), Japan, Latvia (EU), Lithuania (EU), Luxembourg (EU/ESA), Malta (EU), Netherlands (EU/ESA), New Zealand, Norway (ESA), Poland (EU), Portugal (EU/ESA), Republic of Korea, Romania (EU), Russian Federation, Slovakia (EU), Slovenia (EU), South Africa, Spain (EU/ESA), Sweden (EU/ESA), Switzerland (ESA), Turkey, Ukraine, the United Kingdom (EU/ESA), and the United States; 26 out of the current 27 EU member statesonly Cyprus is missing - and all 18 ESA member states are participating in the Arrangement.

27. In comparison with the MTCR membership, Brazil and Iceland are not participating in the Wassenaar Arrangement, while Croatia, Estonia (EU), Latvia (EU), Lithuania (EU), Malta (EU), Romania (EU), Slovakia (EU) and Slovenia (EU) are participating in the Wassenaar Arrangement, but not MTCR.

28. The 1949 Coordinating Committee on Multilateral Export Controls (CoCom) was established in 1949, as a joint organization of the member states of NATO, Japan and Australia, to prevent the sale of weapons and technology to the Soviet Union and its communist allies. CoCom was disbanded in 1994, following the dissolution of the Soviet Union in 1991 and the concurring de facto end of the Cold War, which inter alia resulted in the opening up in principle of Russian and Eastern European markets. See Waldrop (note 20): 191; also Michael Lipson, "The Reincarnation of CoCom: Explaining Post-Cold War Export Controls," The Nonproliferation Review (1999): 33-51.

29. See Wassenaar Arrangement (note 25): Article I (1).

30. See Wassenaar Arrangement (note 25): Article II (3).

31. See Wassenaar Arrangement (note 25): Article II (4), III (1); also, see Wassenaar Arrangement (note 25): Appendix 5.

32. Wassenaar Arrangement (note 25): Dual-Use List, General Technology Note, 3. In the corresponding clause in the USML, technical data do not include "information concerning general scientific, mathematical or engineering principles commonly taught in schools, colleges and universities [basic scientific research] or information in the public domain;" 22 C.F.R., § 120.10(a) (5); "public domain" then being defined in great detail by $\S 120.11$ (a) as including "information ... published 
and ... generally accessible or available to the public ... through patents available at any patent office" - which, however, is not the same as "the minimum necessary information for patent applications." Also, see Meredith and Fleming (note 1): 45.

33. See Wassenaar Arrangement (note 25): Article IV (1).

34. It may be noted that the respective memberships of the MTCR and the Wassenaar Arrangement, though largely similar, do not completely overlap, which might be one reason their respective applications might still have been the subject of discussion periodically.

35. ESA currently counts 18 member states: Austria, Belgium, Czech Republic, Denmark, Finland, France, Germany, Greece, Ireland, Italy, Luxembourg, Netherlands, Norway, Portugal, Spain, Sweden, Switzerland, and the United Kingdom. Of these, Norway and Switzerland are not members of the European Union.

36. Though in practice the concept of "research and development" was interpreted rather broadly - as for example including full-fledged satellite operations and astronaut activities on board of the International Space Station - ESA did stop short of non-experimental space activities. Whenever an experimental activity had matured sufficiently for operation more routinely, ESA would "branch off" those activities to specific entities - Arianespace for launching service provision, Eutelsat, which has since been privatized, for satellite communications and Eumetsat for meteorological satellite operations.

37. Article II, Convention for the Establishment of a European Space Agency (hereafter, ESA Convention), Paris, completed 30 May 1975, entered into force 30 October 1980; 14 ILM 864 (1975).

38. See Gabriel Lafferanderie, European Space Agency (2005), 44-45; and K. Madders, A New Force at a New Frontier, Europe's Development in the Space Field of Its Main Actors, Policies, Law and Activities from its Beginnings up to the Present (Cambridge, UK, Cambridge University Press, 1997), 184-187.

39. Arianespace was originally created like a Groupement d'Interet Economique subsidiary to the French governmental space agency (Centre National d'Etudes Spatiales, CNES), which also was and remains its largest individual shareholder; see Statuts de la Société Arianespace, 26 March 1980.

40. ESA Convention (note 37): Article III (1).

41. ESA Convention (note 37): Article XI (5.j).

42. The European Community, as it was until 1992-1993, was based on the three original treaties of the 1950s (Treaty establishing the European Coal and Steel Community, Paris, done 18 April 1951, entered into force 23 July 1952, 126 UNTS 140; Treaty establishing the European Atomic Energy Community, Rome, done 25 March 1957, entered into force 1 January 1958, 298 UNTS 167; and the Treaty of Rome, or Treaty establishing the European Economic Community (also EEC Treaty), Rome, done 25 March 1957, entered into force 1 January 1958, 298 UNTS 11). Then, the Treaty on European Union, Maastricht, done 7 February 1992, entered into force 1 November 1993, 31 ILM 247 (1992), OJ C 191/1 (1992); the EEC Treaty merged into the EC Treaty and the three existing communities under the overarching heading of the European Union.

43. See EC Treaty (note 42): Article 2-5, referring to the tasks and objectives of the Community, not offering any, even indirect, reference to matters of a defense or military nature, while also indicating that it "shall act within the limits of the powers conferred upon it by this Treaty and of the objectives assigned to it therein."

44. See Treaty on European Union (note 42): Article 11-28.

45. The Commission "shall give its opinion particularly on whether the enhanced cooperation proposed [by EU member states] is consistent with Union policies," Article 27c, Treaty on European Union, as inserted by the Treaty of Nice amending the Treaty on European Union, the Treaties establishing the European Communities and certain related acts (hereafter, Treaty of Nice), Nice, completed 26 February 2001, entered into force 1 February 2003, OJ C 80/1 (2001).

46. Treaty on European Union, as inserted by the Treaty of Nice (note 45): Article 27b.

47. The North Atlantic Treaty Organization (NATO) was established by the North Atlantic Treaty, Brussels, completed 4 April 1949, entered into force 24 August 1949, 34 UNTS 243, TIAS No. 1964, 63 Stat. 2241.

48. The Western European Union (WEU) was established in its original version by the Treaty of Economic, Social and Cultural Collaboration and Collective Self-Defence, Brussels, completed 17 March 1948, entered into force 25 August 1948, and repeatedly amended in the decades since.

49. See Ralph H. Folsom, Principles of European Union Law (2005), 25. 
50. Treaty on European Union, as inserted by the Treaty of Nice (note 45): Article 17.

51. See Council Resolution on the European Contribution to the Development of a Global Navigation Satellite System (GNSS), of 19 December 1994, OJ C 379/2 (1994); Communication from the Commission to the Council and the European Parliament-Towards a Trans-European Positioning and Navigation Network: including A European Strategy for Global Navigation Satellite Systems (GNSS), COM(1998) 29 final, of 21 January 1998; Galileo-Involving Europe in a New Generation of Satellite Navigation Services, of 10 February 1999, COM(1999) 54 final; Council Resolution on the involvement of Europe in a new generation of satellite navigation service-Galileo-Definition phase, of 19 July 1999, OJ C 221/01 (1999); Commission Communication to the European Parliament and the Council-On GALILEO, of 22 November 2000, COM(2000) 750 final; Council Regulation setting up the Galileo Joint Undertaking, No. 876/2002/EC, of 21 May 2002, OJ L 138/1 (2002); and Council Regulation on the establishment of structures for the management of the European satellite radio-navigation programs, No. 1321/2004/EC, of 12 July 2004, OJ L 246/1 (2004).

52. One of the key services which Galileo is going to offer concerns the Public-Regulated Service (PRS), which is going to be encrypted and provided with a certain measure of technical robustness against interference, and is intended for usage by government services or specific government-monitored or government-protected services [such as telecommunication networks] only. Several EU member states, most notably France, have already indicated that they envisage usage of the PRS also by their respective militaries, though this has not been generally accepted yet.

53. See Article 3 (3), Convention on the International Maritime Satellite Organization (INMARSAT), London, completed 3 September 1976, entered into force 16 July 1979, 1143 UNTS 105, TIAS 9605, 31 UST 1, UKTS 1979 No. 94, Cmd. 6822, ATS 1979 No. 10, 15 ILM 1052 (1976).

54. See Geraldine M. Goh, "Keeping the peace in outer space: a legal framework for the prohibition of the use of force," Space Policy 20 (2004): 268-270; and Mark J. Sundahl, “Information Warfare: The Legal Aspects of Using Satellites and Jamming Technologies in Information Battles," Proceedings of the Forty-Ninth Colloquium on the Law of Outer Space (2007), 359-360.

55. Inmarsat was privatized by means of the Convention on the International Mobile Satellite Organization, London, done 3 September 1976, entered into force 16 July 1979, as amended 1998, amended version entered into force 31 July 2001. Under the new arrangement, the applicable Public Service Agreement binding upon the privatized Inmarsat still required the operator to "act exclusively for peaceful purposes;" Article 2.3, Public Service Agreement. Also, see John B. Gantt, "The Concept of 'Peaceful Purposes' /'Peaceful Uses' in the Exploration and Use of Outer SpaceSome Practical Examples," Proceedings of the Forty-Sixth Colloquium on the Law of Outer Space (2004), 110; and Francis Lyall, "The Protection of the Public Interest in the Light of the Commercialization and Privatization of the Providers of International Satellite Communications," Proceedings of the Forty-Seventh Colloquium on the Law of Outer Space (2005), 444.

56. See Council Resolution on the launch of the initial period of global monitoring for environment and security (GMES), of 13 November 2001, OJ C 350/4 (2001); Communication from the Commission to the European Parliament and the Council-Global Monitoring for Environment and Security (GMES): Establishing a GMES capacity by 2008, COM(2004) 65 final, of 3 February 2004. See further on this, the author's "The 'S' of 'Security': Europe on the Road to GMES," Soochow Law Journal 4-2 (2007): 1-27.

57. Council Regulation setting up a Community regime for the control of exports of dual-use items and technology, No. 1334/2000/EC, of 22 June 2000, OJ L 159/1 (2000). A few precursor EC documents on export controls may be mentioned, such as Council Regulation setting up a Community regime for the control of exports of dual-use goods, No. 3381/94/EC, of 19 December 1994, OJ L 367/1 (1994); Council Decision on the joint action adopted by the Council of the basis of Article J.3 of the Treaty on European Union concerning the control of exports of dual-use goods, 94/942/ CFSP, of 19 December 1994, OJ L 367/8 (1994); and even further back Regulation of the Council establishing common rules for exports, (EEC) No. 2603/69, of 20 December 1969, OJ L 324/25 (1969). Note however that these were far from comprehensive in scope.

58. Paragraphs (2), (3), Preamble, Regulation 1334/2000; and Article 1, Paragraphs 4 and 5 further point to the need to harmonize the then-existing regime as per Regulation 3381/94 and Decision 94/942/CFSP by extending the common lists developed already under the latter. 
59. Preamble, Regulation 1334/2000 (note 58): Paragraph (3).

60. Annex I-List of Dual-Use Items and Technology, Council Regulation amending and updating Regulation (EC) No 1334/2000 setting up a Community regime for the control of exports of dualuse items and technology, No. 1167/2008/EC, of 24 October 2008, OJ L 325/3 (2008). The Chemical Weapons Convention is the Convention on the Prohibition of the Development, Production, Stockpiling and Use of Chemical Weapons and on Their Destruction, Paris, done 13 January 1993, entered into force 29 April 1997, 32 ILM 800 (1993).

61. Preamble, Regulation 1334/2000 (note 58): Article 2(a). The definition in the U.S. CCL of 'dualuse:" "Items that have both commercial and military or proliferation applications;" 15 C.F.R., § 772.1, at p. 591.

62. Preamble, Regulation 1334/2000 (note 58): Article 2(b) (iii). The definition in the U.S. ITAR of 'export:' "Sending or taking a defense article out of the United States in any manner, except by mere travel outside of the United States by a person whose personal knowledge includes technical data; or (2) Transferring registration, control or ownership to a foreign person of any aircraft, vessel, or satellite covered by the U.S. Munitions List, whether in the United States or abroad; or (3) Disclosing (including oral or visual disclosure) or transferring in the United States any defense article to an embassy, any agency or subdivision of a foreign government (e.g., diplomatic missions); or (4) Disclosing (including oral or visual disclosure) or transferring technical data to a foreign person, whether in the United States or abroad; or (5) Performing a defense service on behalf of, or for the benefit of, a foreign person, whether in the United States or abroad; or (6) A launch vehicle or payload shall not, by reason of the launching of such vehicle, be considered an export for purposes of this subchapter. However, for certain limited purposes ... the controls of this subchapter may apply to any sale, transfer or proposal to sell or transfer defense articles or defense services;" 22 C.F.R., § 120.17. Also, see Meredith and Fleming (note 1): 46-47, and the definitions of "foreign person" and "defense service" for these purposes.

63. Preamble, Regulation 1334/2000 (note 58): See Article 2(c).

64. Annex I, Regulation 1167/2008 (note 60): OJ L 325/21. The USML has a comparable term “technical data," which is defined as: "(1) Information, other than software as defined in Sec. 120.10(a) (4), which is required for the design, development, production, manufacture, assembly, operation, repair, testing, maintenance or modification of defense articles. This includes: (1) information in the form of blueprints, drawings, photographs, plans, instructions or documentation; (2) classified information relating to defense articles and defense services; (3) information covered by an invention secrecy order; and (4) software as defined in Section 121.8(f) of this subchapter directly related to defense articles:" 22 C.F.R., § 120.10(a); Also, see Meredith and Fleming (note 1): 48 Preamble, Regulation 1334/2000 (note 58):49.

65. Preamble, Regulation 1334/2000 (note 58): Article 11.

66. Council Regulation amending Regulation (EC) No. 1334/2000 (note 58) with regard to intra-Community transfers and exports of dual-use items and technology, No. 2889/2000/EC, of 22 December 2000, OJ L 336/14 (2000).

67. Council Regulation amending Regulation (EC) No. 1334/2000 (note 58) with regard to the list of controlled dual-use items and technology when exported, No. 458/2001/EC, of 6 March 2001, OJ L 65/19 (2001).

68. Council Regulation amending and updating Regulation (EC) No. 1334/2000 (note 58) setting up a Community regime for the control of exports of dual-use items and technology, No. 2432/2001/ EC, of 20 November 2001, OJ L 338/1 (2001).

69. Council Regulation amending Regulation (EC) No 1334/2000 (note 58) setting up a Community regime for the control of exports of dual-use items and technology, No. 880/2002/EC, of 27 May 2002, OJ L 139/7 (2002).

70. Council Regulation amending and updating Regulation (EC) No 1334/2000 (note 58) setting up a Community regime for the control of exports of dual-use items and technology, No. 149/2003/ EC, of 27 January 2003, OJ L 30/1 (2003).

71. Council Regulation adapting Regulation (EC) No 2003/2003 of the European Parliament and of the Council, Council Regulations (EC) No 1334/2000, (EC) No 2157/2001, (EC) No 152/2002, (EC) No 1499/2002, (EC) No 1500/2003 and (EC) No 1798/2003, Decisions No 1719/1999/EC, No 1720/1999/EC, No 253/2000/EC, No 508/2000/EC, No 1031/2000/EC, No 163/2001/EC, No 
2235/2002/EC and No 291/2003/EC of the European Parliament and of the Council, and Council Decisions 1999/382/EC, 2000/821/EC, 2003/17/EC and 2003/893/EC in the fields of free movement of goods, company law, agriculture, taxation, education and training, culture and audiovisual policy and external relations, by reason of the accession of the Czech Republic, Estonia, Cyprus, Latvia, Lithuania, Hungary, Malta, Poland, Slovenia and Slovakia, No. 885/2004/EC, of 26 April 2004, OJ L 168/1 (2004).

72. Council Regulation amending and updating Regulation (EC) No 1334/2000 (note 58) setting up a Community regime for the control of exports of dual-use items and technology, No. 1504/2004/ EC, of 19 July 2004, OJ L 281/1 (2003).

73. Council Regulation amending and updating Regulation (EC) No 1334/2000 (note 58) setting up a Community regime for the control of exports of dual-use items and technology, No. 394/2006/ EC, of 27 February 2006, OJ L 74/1 (2006).

74. Council Regulation amending and updating Regulation (EC) No 1334/2000 setting up a Community regime for the control of exports of dual-use items and technology, No. 1183/2007/EC, of 18 September 2007, OJ L 278/1 (2007).

75. Council Regulation amending and updating Regulation (EC) No 1334/2000 (note 58) setting up a Community regime for the control of exports of dual-use items and technology, No. 1167/2008/ EC, of 24 October 2008, OJ L 325/1 (2008).

76. Annex I, Regulation 1167/2008 (note 60): OJ L 325/3.

77. Annex I, Regulation 1183/2007 (note 74): OJ L 278/3.

78. Annex I, Regulation 1167/2008 (note 60): OJ L 325/4. There exists identical phrasing under the Wassenaar Arrangement and equivalent phrasing under the USML.

79. Regulation 1334/ 2000 (note 58): especially as per Article 4(5) and 5.

80. See Annex I, Regulation 1167/2008 (note 60): OJ L 325/8.

81. See Annex I, Regulation 1167/2008 (note 60): OJ L 325/9.

82. See Annex I, Regulation 1167/2008 (note 60): OJ L 325/12.

83. See Annex I, Regulation 1167/2008 (note 60): OJ L 325/13.

84. See Annex I, Regulation 1167/2008 (note 60): OJ L 325/14.

85. See Annex I, Regulation 1167/2008 (note 60): OJ L 325/15.

86. See Annex I, Regulation 1167/2008 (note 60): OJ L 325/15.

87. See Annex I, Regulation 1167/2008 (note 60): OJ L 325/15-16.

88. See Annex I, Regulation 1167/2008 (note 60): OJ L 325/16.

89. See Annex I, Regulation 1167/2008 (note 60): OJ L 325/17.

90. See Annex I, Regulation 1167/2008 (note 60): OJ L 325/18.

91. See Annex I, Regulation 1167/2008 (note 60): OJ L 325/19.

92. See Annex I, Regulation 1167/2008 (note 60): OJ L 325/19.

93. See Annex I, Regulation 1167/2008 (note 60): OJ L 325/21.

94. Annex I, Regulation 1167/2008 (note 60): OJ L 325/19.

95. For completeness sake, it may be pointed out that Category 0 would be involved in case nuclear propulsion is involved in international trade related to space, whereas Category 8 may be involved where such activities as launching from the high seas are concerned. Overall, such cases may be expected to be rather exceptional for the time being.

96. See Annex I, Regulation 1167/2008 (note 60): OJ L 325/113-136.

97. Annex I, Regulation 1167/ 2008 (note 60): Item 3D003, OJ L 325/134.

98. Annex I, Regulation 1167/2008 (note 60): Item 3E002, OJ L 325/135.

99. See Annex I, Regulation 1167/2008 (note 60): OJ L 325/137-146.

100. Annex I, Regulation 1167/2008 (note 60): Item 4D003.a, OJ L 325/144.

101. See Annex I, Regulation 1167/2008 (note 60): OJ L 325/147-162.

102. See Annex I, Regulation 1167/2008 (note 60): Item 5E001, OJ L 325/155.

103. It is important to note that an introductory note to Part 2 states: "the control status of 'information security' equipment, 'software', systems, application specific 'electronic assemblies,' modules, integrated circuits, components or functions is determined in Category 5, Part 2 even if they are components or 'electronic assemblies' of other equipment", Annex I, Regulation 1167/2008 (note 60): OJ L 325/156.

104. See Annex I, Regulation 1167/2008 (note 60): OJ L 325/163-194. 
105. Annex I, Regulation 1167/2008 (note 60): Item 6A002, OJ L 325/168-172.

106. See Annex I, Regulation 1167/2008 (note 60): Item 6A004, OJ L 325/176-178.

107. See Annex I, Regulation 1167/2008 (note 60): OJ L 325/191.

108. See Annex I, Regulation 1167/2008 (note 60): OJ L 325/192.

109. Annex I, Regulation 1167/2008 (note 60): OJ L 325/15.

110. Annex I, Regulation 1167/2008 (note 60): OJ L 325/16.

111. See Annex I, Regulation 1167/2008 (note 60): OJ L 325/195-207.

112. See Annex I, Regulation 1167/ 2008 (note 58): Items 7A005, 7A105, OJ L 325/199, 200-201.

113. See Annex I, Regulation 1167/2008 (note 60): Item 7A003, OJ L 325/198.

114. See Annex I, Regulation 1167/ 2008 (note 60): Items 7A102, 7A104, OJ L 325/199, 200.

115. Annex I, Regulation 1167/2008 (note 60): Item 7A117, OJ L 325/201.

116. Annex I, Regulation 1167/2008 (note 60): Item 7E104, OJ L 325/207.

117. See Annex I, Regulation 1167/2008 (note 60): OJ L 325/221-237.

118. For example, Annex I, Regulation 1167/2008 (note 60) items 9A004, 9A104, 9A105, 9A107, 9A120, OJ L 325/223-228.

119. Annex I, Regulation 1167/2008 (note 60): Item 9B006, OJ L 325/229.

120. Annex I, Regulation 1167/2008 (note 60): Item 9C108, OJ L 325/231.

121. Annex II-Community General Export Authorization No EU001, Regulation 1167/2008, OJ L 325/239-240.

122. Other parts deal with the concept of a Community General Export Authorization (CGEA), and with the scope ratione materiae of that authorization.

123. Annex II, Regulation 1167/ 2008 (note 121): Item 7E104, OJ L 325/239.

124. Annex II, Regulation 1167/ 2008 (note 121): Item 9A009.a., OJ L 325/239.

125. Annex II, Regulation 1167/2008 (note 121): Item 9A117, OJ L 325/239.

126. See Article 21(1), Regulation 1334/ 2000 (note 58): explicitly referring to Annex IV.

127. See also Annex I, Regulation 1167/2008 (note 60): OJ L 325/3. For items in Part II, no national general authorization may be given with respect to intra-Community trade.

128. Annex IV, Regulation 1167/2008 (note 126): Item 6B108, OJ L 325/245.

129. Annex IV, Regulation 1167/2008 (note 126): OJ L 325/246. It contains three items only, which are broadly formulated.

130. Annex IV, Regulation 1167/2008 (note 126): Item 7A117, OJ L 325/247. Further items listed concern test, calibration, alignment, or production equipment.

131. Annex IV, Regulation 1167/2008 (note 126): Item 9A004, OJ L 325/247. Further items listed in connection with 9A004 are "Liquid rocket propulsion systems" (item 9A005) and "Solid rocket propulsion systems" (item 9A007.a) used for such vehicles, or even specified categories of components for those (item 9A008.d).

132. Annex IV, Regulation 1167/2008 (note 126): Item 9A104, OJ L 325/247; also, items 9A005, 9A007. a \& 9A008.d apply here.

133. See Annex IV, 1167/2008 (note 126): Item 9A119, OJ L 325/248.

134. Annex IV, Regulation 1167/2008 (note 126): Items 9A105.a, 9A106.c, 9A108.c, OJ L 325/248.

135. See Annex IV, Regulation 1183/2007 (note 126): Item 9A116, OJ L 278, 237.

136. Annex IV, Regulation 1167/2008(note 126): Items 9B115, 9B116, 9D101, 9E001, 9E002, 9E101, and 9E102, OJ L 325/248-249.

137. Part I, Annex IV, Regulation 1167/2008 (note 126): OJ L 325/249.

138. See Regulation 1334/2000 (note 58): Article 3(1); Introductory paragraph, Annex I-List of DualUse Items and Technology, Regulation 1167/2008, OJ L 325/3.

139. See Regulation 1334/2000 (note 58):Article 3(2), 4(1), Article 4(1) in this regard refers to "the development, production, handling, operation, maintenance, storage, detection, identification or dissemination of chemical, biological or nuclear weapons or other nuclear explosive devices or the development, production, maintenance or storage of missiles capable of delivering such weapons."

140. See Regulation 1334/ 2000 (note 58): Article 3(2), 4(4)

141. Regulation 1334/ 2000 (note 58): Article 4(2), Regulation 1334/2000; see further, Article 3(2).

142. The Council formally speaking under the CFSP has the authority to take a "common position" or "joint action" subject to individual member state rights to opt out of such positions or actions; see 
Articles 12-14, especially 14(3), Treaty on European Union (note 42): 23.

143. The OSCE is principally based upon the Conference on Security and Co-Operation in Europe Final Act, Helsinki, done 1 August 1975; and see the Charter of Paris for a New Europe, Paris, done 21 November 1990. These were established for the purposes of maintaining peace and security within Europe broadly speaking.

144. Under Chapter VII of the Charter of the United Nations, San Francisco, done 26 June 1945, entered into force 24 October 1945, USTS 993; 24 UST 2225, 59 Statute 1031, 145 UKTS 805, UKTS 1946 No. 67, Cmd. 6666 and 6711, CTS 1945 No. 7, ATS 1945 No. 1; the UN Security Council can take the necessary measures to preserve international peace and security, including the imposition of arms embargoes; see Article 41 and 42 of the UN Charter.

145. Regulation 1334/2000 (note 58): Article 4(3); see further, Article 3(2).

146. Regulation 1334/ 2000 (note 58): Article 5(1); see further, Article 5(2).

147. Regulation 1334/2000 (note 58): Article 4(5).

148. Regulation 1334/2000 (note 58): See Article 4(6).

149. Regulation 1334/2000 (note 58): See Article 6(1).

150. Regulation 1334/2000 (note 58): Article 6(2).

151. See Annex II, Regulation 1167/2008, OJ L 325/239; Part 1 of Annex II simply provides in full: "This export authorization covers the following items: All dual-use specified in any entry in Annex I of the present Regulation except those listed in Part 2 below."

152. See Annex II, Regulation 1167/2008 (note 151): Part 3, OJ L 325/239.

153. See Annex II, Regulation 1167/2008 (note 151): no. 2, OJ L 325/240.

154. See Annex II, Regulation 1167/2008 (note 151): no. 2 OJ L 325/240.

155. See Annex II, Regulation 1167/ 2008 (note 151): no. 3 OJ L 325/240.

156. See Regulation 1334/ 2000 (note 58): Article 5, 6(2).

157. Regulation 1334/2000 (note 58): Article 8, 9(2).

158. Regulation 1334/2000 (note 58): Article 5(1) and (2).

159. See Regulation 1334/2000 (note 58): Article 6(2).

160. See Regulation 1334/ 2000 (note 58): Article 8.

161. Regulation 1334/2000 (note 58): See Article 7(1).

162. Regulation 1334/2000 (note 58): Article 6(5). Actually, this clause provides that member states must maintain or introduce in national legislation the possibility of granting such a global authorization.

163. Regulation 1334/2000 (note 58): Article 10(3).

164. See Regulation 1334/ 2000 (note 58): Article 6(4), 4(1), (2) \& (3).

165. See Regulation 1334/2000 (note 58): Article 6(3); also Article 21(1).

166. See Annex IV, Regulation 1167/ 2008 (note 151): Part I, OJ L 325/245-249. 